\title{
Perbedaan Prestasi Belajar Mahasiswa Prodi PJKR-FIK Universitas Negeri Malang Angkatan 2017 Antara Semester Genap 2018/2019 Dengan Semester Genap 2019/2020
}

\author{
Annisa Cikal Maharani Nuhanafia, Siti Nurrochmah* \\ Universitas Negeri Malang, Jl. Semarang No. 5 Malang, Jawa Timur, Indonesia \\ *Penulis korespondensi, Surel: siti.nurrochmah.fik@um.ac.id
}

Paper received: 2-12-2021; revised: 20-12-2021; accepted: 28-12-2021

\begin{abstract}
The Covid-19 pandemic, which has attacked in all countries, especially in Indonesia in 2020, has changed the learning methods at education levels of education in Indonesia, especially learning for elementary school (SD) to college or University levels. This study examines the value of learning achievement of students of the PJKR FIK study program, State University of Malang. The purpose of this study was to determine and assess whether there was a significant difference in the learning achievement scores of the 2017 Off A class of student theory and practice between the 2018/2019 and even 2019/2020 semesters in the PJKR FIK study program, State University of Malang. This research is included in the ex post facto study using a causal comparative design. The sample of this study was 37 students of the PJKR offering A class of 2017. Data analysis in this study used the Kolmogorov-Smirnov normality test technique, the homogeneity test (Ftest), and the difference test in the form of an unrelated sample t test. Based on the data analysis, the result obtained by the coefficient $T_{\text {count }}$ greater than or equal to $T_{\text {table }}$ at a significant level of 0,05 , meaning that $\mathrm{H}_{0}$ is rejected and $\mathrm{H}_{1}$ is accepted. This means that there is a significant difference in the learning achievement values of the theory and practice subject in the 2018/2019 and even 2019/2020 semesters in the 2017 A class Offering students of the PJKR FIK study Program, State University of Malang.
\end{abstract}

Keywords: learning achievement; even semester; offline and online learning

\begin{abstract}
Abstrak
Pandemi Covid-19yang menyerang di semua negara khususnya di negara Indonesia pada tahun 2020 ini, merubah metode pembelajaran pada jenjang pendidikan yang ada di Indonesia khususnya pembelajaran dari jenjang Sekolah Dasar (SD) sampai ke jenjang Perguruan Tinggi atau Universitas. Penelitian ini mengkaji nilai prestasi belajar mahasiswa program studi PJKR FIK Universitas Negeri Malang. Tujuan dari penelitian ini adalah untuk mengetahui dan mengkaji ada tidaknya perbedaan yang signifikan nilai prestasi belajar mata kuliah teori dan praktek mahasiswa angkatan 2017 off A antara semester genap 2018/2019 dan genap 2019/2020 pada prodi PJKR FIK Universitas Negeri Malang. Penelitian ini termasuk dalam penelitian expost facto dengan menggunakan rancangan causal comparative. Sampel penelitian ini berjumlah 37 mahasiswa Prodi PJKR offering A angkatan tahun 2017. Analisis data pada penelitian ini menggunakan teknik uji normalitas Kolmogorovsmirnov, uji homogenitas (uji F), dan uji beda dalam bentuk uji t sampel berhubungan. Berdasarkan analisis data diperoleh hasil koefisien $\mathrm{T}_{\text {hitung }}$ lebih besar sama dengan $\mathrm{T}_{\text {tabel }}$ pada taraf signifikan 0,05 , artinya bahwa $\mathrm{H}_{0}$ ditolak dan $\mathrm{H}_{1}$ diterima. Artinya, ada perbedaan yang signifikan hasil prestasi belajar antara semester genap 2018/2019 (sebelum pandemi Covid-19) dengan semester genap 2019/2020 (sebelum dan saat pandemi Covid-19) pada mahasiswa offering A angkatan 2017 program studi PJKR FIK Universitas Negeri Malang.
\end{abstract}

Kata kunci: prestasi belajar; semester genap; pembelajaran luring dan daring

\section{Pendahuluan}

Pendidikan merupakan ilmu pengetahuan yang diturunkan dari generasi ke generasi, dikarenakan pendidikan itu sangat penting untuk mencapai sebuah kesuksesan untuk 
menimba ilmu yang sudah diberikan dari seorang pendidik. Ahmadi (2014) mengemukakan pendidikan merupakan ilmu yang sangat bermanfaat di masa yang akan datang dan Pendidikan merupakan suatu proses timbal balik antara pendidik dan siswa dan faktor lingkungan di sekolah. Sesuai dengan UU Republik Indonesia. No. 20 tahun 2003 tentang Sistem Pendidikan Nasional menyatakan bahwa Pendidikan Nasional berfungsi untuk mencerdaskan kehidupan bangsa, mengembangkan potensi peserta didik, dan mengembangkan kemampuan potensi peserta didik agar peserta didik memiliki ilmu, berakhlak mulia, sehat kreatif mandiri serta bertanggung jawab.

Thobroni \& Mustofa (2013) mengemukakan bahwa belajar yaitu proses perubahan tingkah laku atau potensi perilaku untuk hasil dari latihan atau pengalaman secara berulangulang yang akan dicapai oleh peserta didik. Seseorang dianggap belajar jika peserta didik menunjukkan sebuah perilakunya. Sesuai dengan konsep tersebut belajar adalah suatu kegiatan untuk peserta didik agar belajar lebih aktif mencari, dan menyimpulkan suatu masalah. Prinsip-prinsip belajar yang paling utama yaitu adanya perubahan tingkah laku atau perilaku sebagai hasil belajar secara berulang-ulang yang mempunyai ciri-ciri tertentu. Thobroni \& Mustofa (2013) mengemukakan bahwa hasil belajar memiliki kriteria ciri-ciri antara lain (1) Hasil perubahan dari diri sendiri (2) Berkesinambungan atau kontinu dengan perilaku yang lainnya, (3) Bermanfaat ilmu sebagai bekal hidup, (4) Berpikir positif (5) Aktif segala hal yang telah dilakukan dan direncanakan, (6) Memiliki tujuan dan terarah, (7) Mencakup keseluruhan potensi. Berdasarkan ciri-ciri tersebut yaitu belajar merupakan sebuah aktivitas manusia yang dilakukan secara berulang-ulang dan secara terus menerus. Belajar sebaiknya mengoptimalkan proses dan hasil. Yang dimaksud mengoptimalkan yaitu proses dan hasil belajar berarti melakukan berbagai perbaikan dan belajar secara terus-menerus atau secara berulang-ulang agar hasil belajar tersebut berjalan secara optimal dan efektif. (Arifin, 2017) Proses belajar dikatakan optimal dan efektif jika peserta didik selalu aktif mengikuti kegiatan belajar dan pembelajaran. Hasil belajar yang optimal dapat dilihat dari menyelesaikan ketuntasan proses belajar dan mengerjakan tugas secara terampil. Hasil belajar yang efektif merupakan suatu proses atau perolehan belajar yang secara optimal.

Rahyuni (2012) berpendapat bahwa pembelajaran adalah ilmu pengetahuan yang dibantu memberikan ilmu dari seorang pendidik kepada peserta didik agar terjadi adanya proses pembelajaran penguasaan ilmu pengetahuan, membentuk sikap percaya diri, kemahiran dalam pembelajaran adanya interaksi antara pendidik dan peserta didik agar pembelajaran sesuai dengan apa yang diinginkan. Proses pembelajaran dalam konteks pendidikan yaitu pendidikan di lingkungan sekolah agar tercapainya suatu pembelajaran yang optimal, (Winataputra, 2014). Dari beberapa pendapat para ahli dapat disimpulkan bahwa pembelajaran yaitu proses interaksi antara pendidik dengan peserta didik pada suatu lingkungan dan sumber belajar untuk mendapatkan sebuah ilmu yang bermanfaat. Demikian pembelajaran adalah konsep dari belajar, belajar dilakukan secara berulang-ulang dan pembelajaran menjadi satu rangkaian dari belajar untuk melakukan kegiatan pembelajaran yang tidak dapat dipisahkan sehingga adanya proses pembelajaran untuk peserta didik. Hasil dari belajar yaitu suatu proses pembelajaran yang dilaksanakan agar tercapainya pembelajaran yang optimal. Pembelajaran ini bersifat interaktif antara pendidik dan peserta didik yang artinya pembelajaran yang bersifat terarah antara pendidik dengan peserta didik. Sedangkan komunikatif artinya guru dan siswa harus dapat saling memberi, menerima, dan memahami. 
Thobroni \& Mustofa (2013) berpendapat bahwa hasil belajar yaitu pengetahuan, keterampilan dan sikap. Hasil belajar diperoleh berdasarkan hasil penilaian dari dosen pengampu matakuliah teori dan praktek. Hasil penilaian terhadap unjuk kerja mahasiswa mencerminkan dari kemampuan peserta didik dalam mencapai kompetensinya untuk menentukan langkah-langkah berikutnya (Komarudin, 2016). Proses pembelajaran dalam Pendidikan jasmani ini merupakan pembelajaran melalui aktivitas gerak untuk mengembangkan keterampilan motorik, hidup sehat dan aktif. Dalam aktivitas gerak ini peserta didik dapat menguasai keterampilan, pengetahuan dan mengembangkan keterampilan yang dimiliki dari setiap individu, memperbaiki kondisi fisik dan mengembangkan nilai sikap yang positif. Tujuan pendidikan jasmani yaitu pembelajaran lebih ditekankan pada aspek psikomotor untuk mengembangkan kebugaran jasmani dan mengembangkan keterampilan gerak psikomotor.

Bentuk perkuliahan dalam konteks pembelajaran yang dapat dilakukan di masa pandemi Covid-19 ini yaitu dengan menggunakan metode pembelajaran daring atau disebut dengan pembelajaran online. (Dickson, 2011) menyatakan bahwa pembelajaran daring merupakan pembelajaran yang tidak bisa lepas dari jaringan internet agar pembelajaran tetap berjalan dengan lancar maka pembelajaran daring sangat memerlukan fasilitas menggunakan jaringan internet yaitu dengan adanya aksesibilitas, konektivitas, fleksibilitas, dan kemampuan untuk memunculkan berbagai jenis interaksi pembelajaran online agar proses pembelajaran daring ini dapat berjalan sesuai dengan yang diinginkan. Sedangkan pembelajaran perkuliahan daring menurut (Kuntarto, 2017) yaitu pembelajaran yang mampu mempertemukan mahasiswa dan dosen dengan menggunakan jaringan online untuk tetap melakukan pembelajaran dengan menggunakan fasilitas koneksi internet. Pada pembelajaran daring memerlukan dukungan perangkat smartphone android, laptop, computer, yang bisa digunakan untuk mengakses informasi.

Perubahan metode pembelajaran yang dilaksanakan pada semua jenjang pendidikan yang terdapat di Indonesia karena pandemi Covid-19 proses pembelajaran semester genap 2018/2019 menggunakan metode pembelajaran yaitu pembelajaran tatap muka atau disebut dengan pembelajaran luring dan proses pembelajaran semester genap 2019/2020 menggunakan dua metode yaitu pembelajaran tatap muka atau disebut dengan luring dan pembelajaran online atau disebut dengan daring, maka penulis tertarik untuk melakukan penelitian yang berjudul "Perbedaan Prestasi Belajar Mahasiswa Prodi PJKR-FIK Universitas Negeri Malang Angkatan 2017 Antara Semester Genap 2018/2019 Dengan Semester Genap 2019/2020".

\section{Metode}

Penelitian ini termasuk jenis penelitian expost facto yaitu penelitian yang bertujuan mengetahui gejala atau fenomena, menemukan penyebab perubahan perilaku, hal-hal yang menyebabkan perubahan perilaku pada variabel bebas dengan secara keseluruhan yang sudah terjadi (Widarto, 2013). Adapun variabel yang diteliti pada penelitian ini yaitu (a) variabel terikat berupa nilai prestasi belajar mata kuliah teori dan praktek (b) variabel bebas berupa semester genap 2018/2019 dengan semester genap 2019/2020 pada tahun akademik 2018/2019 dengan 2019/2020.

Pada penelitian ini menggunakan metode dokumentasi yang didapatkan dari kartu hasil studi (KHS) dari mahasiswa yang dijadikan sampel dalam penelitian ini. Kartu Hasil Studi 
(KHS) ini merupakan instrumen penelitian yang berupa instrumen non tes yang akan digunakan untuk mengetahui dan mencari data hasil prestasi belajar yang terdapat pada KHS semester genap 2018/2019 dengan semester genap 2019/2020 dari mahasiswa angkatan 2017 offering A Prodi PJKR FIK Universitas Negeri Malang. Populasi pada penelitian ini yaitu mahasiswa angkatan 2017 Off A yang mengikuti pembelajaran pada semester genap 2018/2019 dengan semester genap 2019/2020 yang berjumlah 39 mahasiswa. Pengambilan sampel ini menggunakan teknik purposive proportional systematic random sampling atau pengambilan sampel secara acak dengan porsi 95\% dari jumlah keseluruhan populasi yang sudah ditentukan dengan demikian sampel yang digunakan dalam penelitian ini berjumlah 37 mahasiswa. Pengujian hipotesis yang digunakan untuk penelitian ini menggunakan dengan teknik analisis data berupa teknik uji t sampel tidak berhubungan yang mengharuskan melalui uji prasyarat terlebih dahulu. Uji prasyarat yang dilakukan adalah uji normalitas data dengan menggunakan teknik Kolmogorov Smirnov dan uji homogenitas menggunakan teknik uji T.

\section{Hasil dan Pembahasan}

\subsection{Hasil Analisis Uji Normalitas}

Hasil analisis data pada penelitian ini berupa: Hasil analisis data hipotesis ini menggunakan uji T sampel berhubungan, hasil analisis uji prasyarat yaitu uji normalitas data dengan teknik (Kolmogorov-Smirnov), dan uji homogenitas menggunakan (uji t).

Data uji normalitas ini bertujuan untuk mengetahui data yang sudah diambil dan akan dianalisis apakah data tersebut berdistribusi normal atau berdistribusi tidak normal. Uji normalitas data ini dilakukan terhadap seluruh sampel yang ditentukan yaitu berjumlah 37 mahasiswa dengan nilai dari IP mahasiswa yaitu prestasi belajar matakuliah teori dan praktek semester genap 2018/2019 dengan semester genap 2019/2020 yang didapatkan pada saat pengumpulan data. Analisis data uji normalitas ini menggunakan teknik Kolmogorov-Smirnov. Data dapat dinyatakan apabila $\mathrm{D}_{\text {hitung }}<\mathrm{D}_{\text {tabel }}$ yang dinyatakan bahwa data berdistribusi normal Hasil analisis data uji normalitas disajikan pada tabel berikut ini:

Tabel 1. Penyajian Hasil Analisis Data Uji Normalitas Data Terhadap Variabel Prestasi Belajar Matakuliah Teori dan Praktek Semester genap 2018/2019 dengan genap 2019/2020

\begin{tabular}{|c|c|c|c|c|c|}
\hline No & Variabel & Semester & $\begin{array}{c}\text { Hasil Uji } \\
\text { D } \\
\text { (D hitung) }\end{array}$ & $\begin{array}{c}\text { Tabel D } \\
(\alpha= \\
0,05)\end{array}$ & $\begin{array}{l}\text { Keterangan } \\
(\alpha=0,05)\end{array}$ \\
\hline 1 & Prestasi Belajar & $\begin{array}{l}\text { Genap } \\
2018 / 2019 \text { (IV) }\end{array}$ & 0,09811 & 0,224 & $\begin{array}{l}\text { Dhit. }<D_{\text {tab. }} \alpha=0,05, \\
\text { Data berdistribusi normal }\end{array}$ \\
\hline 2. & $\begin{array}{l}\text { Matakuliah Teori } \\
\text { dan Praktek }\end{array}$ & $\begin{array}{l}\text { Genap } \\
2019 / 2020(\mathrm{VI})\end{array}$ & 0,09126 & 0,224 & $\begin{array}{l}\text { Dhit. }<D_{\text {tab. }} \alpha=0,05 \text {, } \\
\text { Data berdistribusi normal }\end{array}$ \\
\hline
\end{tabular}

Pada Tabel 1 didapatkan hasil analisis data uji prasyarat normalitas data menggunakan teknik Kolmogorov-Smirnov terhadap variabel yang diteliti yaitu prestasi belajar matakuliah teori dan praktik semester genap 2018/2019 dengan genap 2019/2020, hasil analisis data pada variabel prestasi belajar matakuliah teori dan praktik semester genap 2018/2019 koefisien $D_{\text {hitung. }}=0,09811$ dan hasil analisis data pada variabel prestasi belajar matakuliah teori dan praktik semester genap 2019/2020 koefisien $D_{\text {hitung }}=0,09126$. Oleh karena itu pada kedua prestasi belajar matakuliah teori dan praktik semester genap 2018/2019 dengan genap 
$2019 / 2020$ koefisien $D_{\text {hitung }}<D_{\text {tabel }} \alpha=0,05$ yang diartikan bahwa hipotesis kerja $\left(\mathrm{H}_{1}\right)$ ditolak dan hipotesis nihil $\left(\mathrm{H}_{0}\right)$ diterima yang menyatakan data pada variabel prestasi belajar matakuliah teori dan praktik semester genap diterima, berarti hasil prestasi belajar matakuliah teori dan praktik semester genap 2018/2019 dengan genap 2019/2020 hasil menunjukkan bahwa data berdistribusi normal. Sehubungan dengan hasil analisis data uji normalitas menggunakan teknik Kolmogorov-Smirnov, menunjukkan berdistribusi normal, berarti analisis data uji beda bentuk uji t sampel berhubungan dapat dilanjutkan.

\subsection{Hasil Uji T Sampel Berhubungan}

Analisis data yang terakhir ini dengan menggunakan uji beda yaitu uji t sampel berhubungan terhadap variabel prestasi belajar matakuliah teori dan praktek semester genap 2018/2019 dengan semester genap 2019/2020. Berikut disajikan hasil analisis uji beda sampel tidak bebas pada variabel prestasi belajar matakuliah teori dan praktek semester genap 2018/2019 dengan semester genap 2019/2020 pada Tabel 2 berikut ini.

Tabel 2. Penyajian Hasil Analisis Uji Beda Data Tidak Homogen dengan Variabel Prestasi

Belajar Matakuliah Teori dan Praktek Semester Genap 2018/2019 dengan Genap $2019 / 2020$

\begin{tabular}{|c|c|c|c|c|c|c|}
\hline No & Variabel & Semester & Rata-rata & $\begin{array}{c}\text { Hasil Uji } \\
t_{\text {hit. }}\end{array}$ & $\begin{array}{c}t_{\text {tab. }} \text { db. } N-2 \\
(\alpha=0,05)\end{array}$ & $\begin{array}{c}\text { Keterangan } \\
(\alpha=0,05)\end{array}$ \\
\hline 1 & $\begin{array}{l}\text { Prestasi } \\
\text { belajar } \\
\text { Matakuliah } \\
\text { teori dan } \\
\text { Praktik }\end{array}$ & $\begin{array}{l}\text { Genap } \\
2018 / 2019 \\
\text { Genap } \\
2019 / 2020\end{array}$ & $\begin{array}{l}3,1 \\
3,6\end{array}$ & $-9,01$ & 2,028 & $\begin{array}{l}\text { thitung. }_{\text {. }}<t_{\text {tabel. }} \alpha=0,05 \\
\text { Ada perbedaan yang } \\
\text { signifikan dari hasil } \\
\text { prestasi belajar } \\
\text { matakuliah teori dan } \\
\text { praktik antara } \\
\text { semester genap } \\
2018 / 2019 \text { dengan } \\
\text { genap } 2019 / 2020 .\end{array}$ \\
\hline
\end{tabular}

Pada tabel 2 ini hasil analisis data pada uji t diatas, menunjukkan bahwa hasil analisis data pada variabel prestasi belajar matakuliah teori dan praktik semester genap Tahun akademik genap 2018/2019 dengan genap 2019/2020 diperoleh koefisien $t_{\text {hitung }}=-9,01$, dan $t_{\text {tabel } \alpha 0,05}=2,028$. Berdasarkan hasil analisis uji $t$ tersebut menunjukkan bahwa $T_{\text {hitung }}>T_{\text {tabel, }}$ nilai yang diperoleh $-9,01>2,028$, maka hipotesis kerja $\left(\mathrm{H}_{0}\right)$ ditolak dan hipotesis kerja $\left(\mathrm{H}_{1}\right)$ diterima. Berarti dapat disimpulkan yaitu ada perbedaan yang signifikan terhadap prestasi belajar matakuliah teori dan praktek semester genap tahun akademik 2018/2019 dengan $2019 / 2020$.

\subsection{Pengujian Hipotesis}

Pengujian hipotesis ini menggunakan pengujian dalam bentuk uji t. Tujuan dari pengujian hipotesis pada penelitian ini adalah ingin mengetahui apakah ada perbedaan terhadap nilai prestasi belajar matakuliah teori dan praktek antar semester genap 2018/2019 dengan genap 2019/2020 pada mahasiswa Offering A Angkatan 2017. Penentuan hipotesis pengujian uji t: 
$\mathrm{H}_{0}=$ Tidak adanya perbedaan yang signifikan hasil prestasi belajar antara semester genap 2018/2019 dengan semester genap 2019/2020.

$\mathrm{H}_{1}=$ Adanya perbedaan yang signifikan hasil prestasi belajar antara semester genap 2018/2019 dengan semester genap 2019/2020.

Untuk pengambilan keputusan sebagai berikut:

1. Apabila $\mathrm{H}_{1}$ ditolak maka $\mathrm{H}_{0}$ diterima, maka dapat disimpulkan tidak ada perbedaan yang signifikan atau $\mathrm{T}_{\text {hitung }}<\mathrm{T}_{\text {tabel }}$ maka $\mathrm{H}_{0}$ diterima dengan taraf signifikan $5 \%(\alpha=0,05)$

2. Apabila $\mathrm{H}_{0}$ ditolak maka $\mathrm{H}_{1}$ diterima, maka dapat disimpulkan ada perbedaan yang signifikan atau $\mathrm{T}_{\text {hitung }}>\mathrm{T}_{\text {tabe }}$ maka $\mathrm{H}_{1}$ diterima dengan taraf signifikan $5 \%(\alpha=0,05)$

Hasil analisis data bentuk uji T antara prestasi belajar mahasiswa angkatan tahun 2017 semester genap 2018/2019 dengan 2019/2020 prodi PJKR Offering A FIK Universitas Negeri Malang maka diperoleh hasil $\mathrm{T}_{\text {hitung. }}-9,01>\mathrm{T}_{\text {tabel }}=-9,01>2,028$ dengan taraf signifikan 0,05 . Dengan demikian dapat disimpulkan bahwa $\mathrm{H}_{0}$ ditolak dan $\mathrm{H}_{1}$ diterima. Maka dapat disimpulkan bahwa ada perbedaan yang signifikan antara hasil belajar matakuliah teori dan praktek semester genap 2018/2019 dengan genap 2019/2020 pada mahasiswa Offering A angkatan tahun 2017 Prodi PJKR FIK-UM.

\subsection{Pembahasan}

Proses pembelajaran yang terjadi pembelajaran yang semula pada semester genap 2018/2019 menggunakan metode pembelajaran luring atau disebut dengan pembelajaran tatap muka akan tetapi dikarenakan adanya Covid-19 proses pembelajaran semester genap 2019/2010 ini berubah menjadi dua metode yaitu pembelajaran luring dan pembelajaran daring. Oleh karena itu proses pembelajaran daring di PJKR FIK UM ini mempengaruhi prestasi belajar matakuliah teori dan praktek. Pada semester genap 2018/2019 proses pembelajaran kegiatan belajar mengajar menggunakan metode pembelajaran luring atau disebut juga dengan pembelajaran tatap muka. Hasbullah (2015) Proses pembelajaran luring sering digunakan dalam proses pembelajaran di jenjang Pendidikan khususnya dari Pendidikan Sekolah Dasar (SD) sampai dengan jenjang Pendidikan Universitas atau perguruan tinggi. Pembelajaran tatap muka atau disebut dengan pembelajaran face to face antara pendidik dan peserta didik ini merupakan pembelajaran secara langsung untuk menyampaikan ilmu pengetahuan kepada peserta didik. Proses pembelajaran luring ini yaitu memiliki karakteristik yaitu terencana sesuai dengan yang diharapkan dan berinteraksi sosial antara pendidik dan peserta didik agar pembelajaran tetap berjalan.

Dalam pembelajaran matakuliah teori ini di dunia mempunyai teknologi yang canggih sehingga Pendidik tidak perlu banyak untuk menjelaskan. Pendidikan saat ini memasuki era dunia media teknologi, dimana dalam kegiatan pembelajaran ini menuntut dikuranginya metode seperti ceramah dikarenakan mahasiswa merasa bosan dan metode ceramah ini bisa diganti dengan menggunakan banyak media seperti pembelajaran presentasi menggunakan LCD proyektor yang bisa dibuat semenarik mungkin sehingga pembelajaran teori ini peserta didik tidak merasa bosan atau jenuh (Nurseto, 2011). Jika mengacu pada perkembangan kurikulum yang saat ini dilakukan peserta didik tidak hanya mendengerkan sebagai penerima pesan dari pendidik, akan tetapi peserta didik diharapkan untuk menyampaikan pesan 
contohnya seperti mahasiswa berpresentasi, memberikan tanya jawab dan memberikan kritik dan saran agar pembelajaran selanjutnya bisa berjalan dengan lancar sehingga terbentuklah pembelajaran, dan adanya komunikasi antara pendidik dan mahasiswa. Dalam komunikasi tersebut, media pembelajaran seperti LCD proyektor dibutuhkan untuk meningkatkan efektifitas pencapaian dari sebuah pembelajaran teori.

Dalam pembelajaran matakuliah praktik/pembelajaran gerak keterampilan ini memerlukan proses dengan latihan atau pengalaman agar terjadi adanya perubahan yang relatif permanen. Bakhtiar (2015) menyatakan pembelajaran pendidikan jasmani merupakan pembelajaran melalui gerak dasar (fundamental motor skill) yang membentuk sebuah gerakan penguasaan keterampilan dengan menggunakan gerakan jari-jari tangan, koordinasi mata, koordinasi tangan, koordinasi kaki, dan juga memerlukan keseimbangan.

Di Dalam pembelajaran teori dan praktek mahasiswa mampu menguasai materi pembelajaran teori dan praktik yang diberikan dosen/pendidik. Agar tujuan tersebut dapat dicapai maka prinsip belajar khususnya belajar gerak penting untuk diterapkan. Bahtiar (2016) menyatakan bahwa prinsip pembelajaran merupakan sumber motivasi agar proses belajar mengajar dapat berjalan dengan baik antara pendidik dan peserta didik dan landasan berpikir pada peserta didik. Sedangkan pembelajaran pada hakikatnya merupakan proses interaksi timbal balik antara peserta didik dan pendidik agar peserta didik dapat melakukan perubahan tingkah laku maupun pengetahuan agar mencapai tujuan yang telah ditetapkan. Thobroni \& Mustofa (2013) menyatakan bahwa prinsip belajar sedapat mungkin menunjukkan kontinuitas atau berkesinambungan artinya keterampilan yang diberikan secara terus menerus banyak dilakukan, dan terlibat aktif yaitu siswa mampu merencanakan gerakan secara berulang-ulang.

Mengapa proses pembelajaran dua metode yaitu pembelajaran luring dan daring lebih baik dari pada pembelajaran luring? Hal ini dikarenakan pelaksanan pembelajaran luring dikarenakan pembelajaran yang cukup membosankan terutama pembelajaran teori, hal ini didasari oleh pengalaman pribadi dari peneliti sendiri yang pernah mengikuti kegiatan perkuliahan pada tahun ajaran 2019/2020. Selama proses belajar-mengajar sedang berlangsung, pembelajaran menggunakan dua metode yaitu pembelajaran luring dan daring, pembelajaran daring ini mahasiswa menggunakan pembelajaran via online berupa aplikasi Google Meet, Edmodo, Zoom, dan Google Classroom. Selama adanya pelaksanaan pembelajaran daring ini, peserta didik memiliki waktu yang panjang untuk belajar. Peserta didik dapat belajar dimana saja dan kapan saja, tanpa dibatasi ruang maupun waktu. Peserta didik juga dapat berkomunikasi dan berinteraksi dengan pendidik pada waktu yang telah disepakati secara bersama, contohnya seperti menggunakan live chat, video call ataupun bisa menggunakan grup kelas yang telah disediakan. Dengan adanya pembelajaran daring ini memiliki tantangan sendiri untuk peserta didik. Peserta didik tidak sangat membutuhkan jaringan koneksi internet yang cukup kuat dan memadai, dan juga membutuhkan suasana dirumah yang mendukung untuk proses belajar mengajar agar proses pembelajaran tetap berjalan dengan lancar. Namun, proses pembelajaran efektif juga harus adanya komunikasi antar guru/dosen dan siswa mengikuti pembelajaran dengan baik, peserta didik aktif mengikuti diskusi dan berinteraksi dalam hal apapun dengan pendidikan dan juga temanteman, harus bisa manajemen waktu untuk mengikuti pembelajaran yang efektif bagi para peserta didik. 
Dalam pembelajaran daring ini peserta didik harus tetap membuat catatan deadline apa saja tugas yang harus yang harus dikumpulkan dan membuat catatan apa saja materi yang telah diberikan oleh pendidik. Dalam proses pembelajaran luring dan daring harus tetap dilaksanakan ditengah wabah pandemi Covid-19. Karena,tidak mungkin peserta didik libur panjang atau di diamkan Dikarenakan setiap ilmu yang dijelaskan oleh pendidik itu sangat penting dan berguna untuk menambahkan ilmu yang kita dapati. Pelaksanaan proses pembelajaran daring atau online ini dilaksanakan dalam rangka pencegahan penyebaran Covid-19 di lingkungan pendidikan sesuai dengan Surat Edaran Kemendikbud Dikti No. 3 Tahun 2020 (Kemdikbud, 2020). Proses pelaksanaan pembelajaran online ini yaitu menggunakan pembelajaran dengan menggunakan jaringan internet (Zhafira, 2020).

\section{Simpulan}

Berdasarkan hasil analisis data pada penelitian prestasi belajar matakuliah teori dan praktik semester genap 2018/2019 dengan genap 2019/2020 mahasiswa Offering A angkatan 2017 Program Studi PJKR FIK Universitas Negeri Malang yang sudah dilakukan, maka penelitian disimpulkan bahwa ada perbedaan yang signifikan antara prestasi belajar mahasiswa angkatan tahun 2017 semester genap 2018/2019 dengan semester genap 2019/2020 prodi PJKR FIK Universitas Negeri Malang.

\section{Daftar Rujukan}

Ahmadi, A \& Supriyono, W. (2011). Psikologi Belajar. Jakarta: Rineka Cipta.

Cahyono, A. (2020). Survei Persepsi Siswa Terhadap Konsep Pendidikan Jasmani SMP Kelas VIII. Sport Science and Health, 2(12), 605-612.

Dani, Y. M., Maridi, M., \& Sugiharto, B. (2015). Peningkatan Keaktifan dan Motivasi Belajar Biologi Melalui Discovery Learning pada Siswa Kelas XI IPA ICT 2 SMA Muhammadiyah 1 Karanganyar Tahun Pelajaran 2014/2015. BIO-PEDAGOGI, 5(1), 1-5.

Darwis, D. M. (2017). Pengaruh Kualitas Guru Terhadap Kemampuan Guru Dalam Memvariasikan Pembelajaran. Tazkir: Jurnal Penelitian Ilmu-ilmu Sosial dan Keislaman, 3(1), 195-206.

Depdiknas. (2006). Kurikulum Tingkat satuan Pendidikan (KTSP) untuk Sekolah Dasar/ MI. Jakarta: Terbitan Depdiknas.

Dina, K. R. (2020). Pembelajaran Luring. Jakarta: Adab

Fakhrurrazi, F. (2018). Hakikat pembelajaran yang efektif. At-Tafkir, 11(1), 85-99.

Fathurrohman. (2017). Belajar dan Pembelajaran Modern. Yogyakarta: Garudhawaca.

Hadiana, D. (2015). Penilaian Hasil Belajar untuk Siswa Sekolah Dasar. Jurnal Pendidikan dan Kebudayaan, 21(1), 15-26.

Hanafy, M. S. (2014). Konsep belajar dan pembelajaran. Lentera Pendidikan: Jurnal Ilmu Tarbiyah dan Keguruan, 17(1), 66-79.

Hidayah, A. A. F., Al Adawiyah, R., \& Mahanani, P. A. R. (2020). Efektivitas Pembelajaran Daring di Masa Pandemi Covid-19. JURNAL SOSIAL: Jurnal Penelitian Ilmu-IImu Sosial, 21(2), 53-56.

Islamiah, A. I., Roesdiyanto, R., \& Ariwinanti, D. (2019). Perbedaan Pengetahuan Siswa Tentang Infeksi Menular Seksual (IMS) Menggunakan Metode Ceramah dan Metode Brainstorming di Sekolah Menengah Atas. Sport Science and Health, 1(3), 176-183.

Kadir. (2015). Statistika Terapan: Konsep, Contoh, dan Analisa Data dengan Program SPSS/Lisrel dalam Penelitian. Jakarta: PT Rajagrafindo Persada.

Kemdikbud, (2003). Undang-undang Republik Indonesia Nomor 20 tahun 2003 tentang Sistem Pendidikan Nasional. Diakses 25 Agustus 2020, dari http://simkeu.kemdikbud.go.id/index.php/peraturan1/8-uuundang-undang/12-uu-no-20-tahun-2003-tentang-sistem-pendidikan-nasional.

Kemdikbud. (2016). KBBI Daring. Diakses 26 Agustus 2020, dari https://kbbi kemdikbud.go.id/entri/pendidikan. 
Komarudin. (2016). Penilaian Hasil Belajar Pendidikan Jasmani dan Olahraga. Bandung: PT Remaja Rosdakarya.

Kuntarto, E. (2017). Keefektifan model pembelajaran daring dalam perkuliahan bahasa Indonesia di perguruan tinggi. Journal Indonesian Language Education and Literature, 3(1).

Nazir. (2014). Metode Penelitian. Bogor: Ghalia Indonesia.

Nurdyansyah. (2015). Inovasi Teknologi Pembelajaran. Sidoarjo: Nizamial Learning Center.

Pangondian, R. A., Santosa, P. I., \& Nugroho, E. (2019, February). Faktor-faktor yang mempengaruhi kesuksesan pembelajaran daring dalam revolusi industri 4.0. In Seminar Nasional Teknologi Komputer \& Sains (SAINTEKS) (Vol. 1, No. 1).

Rahyubi, H. (2014). Teori-teori Belajar dan Aplikasi Pembelajaran Motorik. Bandung: Nusa Media.

Rosyid, M. Z. (2019). Prestasi Belajar. Malang: Literasi Nusantara.

Rusdiana, E., \& Nugroho, A. (2020). Respon mahasiswa pada pembelajaran daring bagi mahasiswa mata kuliah pengantar hukum Indonesia UNESA. Integralistik, 31(1), 1-12.

Safitri, A. (2017). Keefektifan Model Examples Non Examples Terhadap Keterampilan Menulis Karangan Narasi Pada Siswa Kelas Iv Gugus Ki Hajar Dewantoro Kabupaten Sragen. Universitas Negeri Semarang.

Sardirman, A. M. (2011). Interaksi dan Motivasi Belajar Mengajar, Jakarta: Rajawali Pers. Hal 38.

Setiawati, L., \& Sudira, P. (2015). Faktor-faktor yang mempengaruhi prestasi belajar praktik kejuruan siswa SMK program studi keahlian teknik komputer dan informatika. Jurnal Pendidikan Vokasi, 5(3), 325-339.

Suardi. (2018). Belajar dan Pembelajaran. Yogyakarta: Deepublish Publisher.

Suyono \& Hariyanto. (2014). Belajar dan Pembelajaran Teori dan Konsep Dasar. Bandung: PT Remaja Rosdakarya.

Syaiful, B. D. (2012). Prestasi Belajar dan Kompetensi Guru. Surabaya: Usaha Nasional.

Thaib, E. N. (2013). Hubungan Antara prestasi belajar dengan kecerdasan emosional. JURNAL ILMIAH DIDAKTIKA: Media Ilmiah Pendidikan dan Pengajaran, 13(2)

Thobroni \& Mustofa, A. (2013). Belajar dan Pembelajaran. Jogjakarta: Ar-Ruzz Media.

Wardani, D. N., Toenlioe, A. J., \& Wedi, A. (2018). Daya tarik pembelajaran di era 21 dengan Blended Learning. Jurnal Kajian Teknologi Pendidikan, 1(1), 13-18.

Winataputra, S. (2014). Hakikat Belajar dan Pembelajaran. Jakarta: Universitas Terbuka.

Yanuar, K. (2019). Belajar Keterampilan Motorik. Jakarta: Prenadamedia Group.

Zhafira, N. H., Ertika, Y., \& Chairiyaton, C. (2020). Persepsi mahasiswa terhadap perkuliahan daring sebagai sarana pembelajaran. Jurnal Bisnis Dan Kajian Strategi Manajemen, 4(1). 